\title{
Shelf life of artisanal demi-glace sauce
}

\author{
Natálya Vidal de HOLANDA ${ }^{1}$, Joyciane da Silva GOMES ${ }^{1}$, Sandra Maria Lopes dos SANTOS ${ }^{1}$, \\ Marlene Nunes DAMACENO ${ }^{1 *}$
}

\begin{abstract}
The objective of this study was to elaborate and evaluate the shelf life of the liquid artisanal demi-glace sauce considering sensory, microbiological and lipid oxidation characteristics during 75 days of storage compared to commercial hydrated demi-glace sauce. Sensory aspects (visual and olfactory), counts of coliform and Staphylococcus aureus, determination of Salmonella sp. and lipid oxidation were evaluated every 15 days. The artisanal demi-glace sauce was homogenous, without sensory alteration during the storage period, with olfactory alteration only at the end. The commercial demi-glace sauce remained unchanged until t3 (30 days), from $\mathrm{t} 4$ ( 45 days) presented turbid appearance, followed by phase separation and with unpleasant odor in t6 (75 days). The lipid oxidation showed an increased concentration of malonaldehyde at every evaluated time. The artisanal and commercial demi-glace sauces showed a significant difference at $\mathrm{t} 1, \mathrm{t} 2, \mathrm{t} 4$ and $\mathrm{t} 5$, when the artisanal sauce had lower contents of malonaldehyde $(18,23,36$ and $11 \%$, respectively), only at the 30th and 75th days of storage there was significant similarity. The sauces were within the microbiological standards required by the law. Although the artisanal demi-glace sauce does not contain conservatives, its shelf life was similar to the hydrated commercial product.
\end{abstract}

Keywords: malonaldehyde; microorganisms; sensory; stability.

Practical Application: The development of the demi-glace sauce, taking advantage of bovine debris residues, is important to provide the market product with better technological conditions of production and lower cost with the acquisition of raw material. The shelf-life study verify and identify the main alterations of food degradation, characterizing the final quality of the product elaborated.

\section{Introduction}

Demi-glace is a translucent, dark brown, consistent sauce with a uniform texture that tops meat dishes, especially beef (Barreto, 2010). It is prepared using bones and beef trimmings. The main disadvantage is its preparation time, which may last more than a day due to its several production stages. Although one of the sauce preparation steps is the extraction of the supernatant fat, it also has a high lipid content, which may make the product susceptible to oxidation, forming undesirable components.

The main food degradation factors, besides lipid oxidation, are changes in moisture content, loss of nutritional value, action of microorganisms and pigment oxidation, resulting in a reduced product shelf life. Shelf life is defined as the time until the product, stored under predetermined conditions, presents changes acceptable to the manufacturer, the consumer and the legislation (Moura et al., 2007). This parameter has a direct connection with production planning, characteristics of ingredients, processing and storage (Forsythe, 2013).

Lipid oxidation is one of the main reactions that may occur during the production, storage and distribution of products that have meat in their formulation. This reaction generates compounds such as aldehydes and derivatives, especially malonaldehyde, which may be harmful to health. Malonaldehyde is the main product of lipid peroxidation and has been used as an oxidative stress marker of meat products (Almeida et al., 2017).
Demi-glace sauce is widely used in world cuisine, however, there are no studies on its shelf life. The products with high fat content, as is the case of the demi-glace sauce, are susceptible to lipid oxidation and consequent alteration of sensorial quality.

The objective of this study was to elaborate and evaluate the shelf life of the liquid artisanal demi-glace sauce assessing sensory, microbiological and lipid oxidation characteristics during 75 days of storage compared to commercial demi-glace sauce after hydrated.

\section{Materials and methods}

\subsection{Preparation of demi-glace sauce samples}

Artisanal demi-glace sauce

The artisanal demi-glace sauce was developed in three stages (Figure 1). The first stage resulted in a dark broth, which first appeared during the cooking of bones and beef trimmings under dry heat at $200{ }^{\circ} \mathrm{C}$ in an electric furnace. After this process, the bones and the baked trimmings were cooked $\left(60-70{ }^{\circ} \mathrm{C}\right)$ for 6 hours with mirepoix (carrot, onion and celery), olive oil, garlic, bay leaf, rosemary, chives, coriander, pepper and annatto natural dye. Then, the separation of the liquid and solid phases was carried out. The liquid was cooled $\left(10^{\circ} \mathrm{C} / 12 \mathrm{~h}\right)$ to remove 


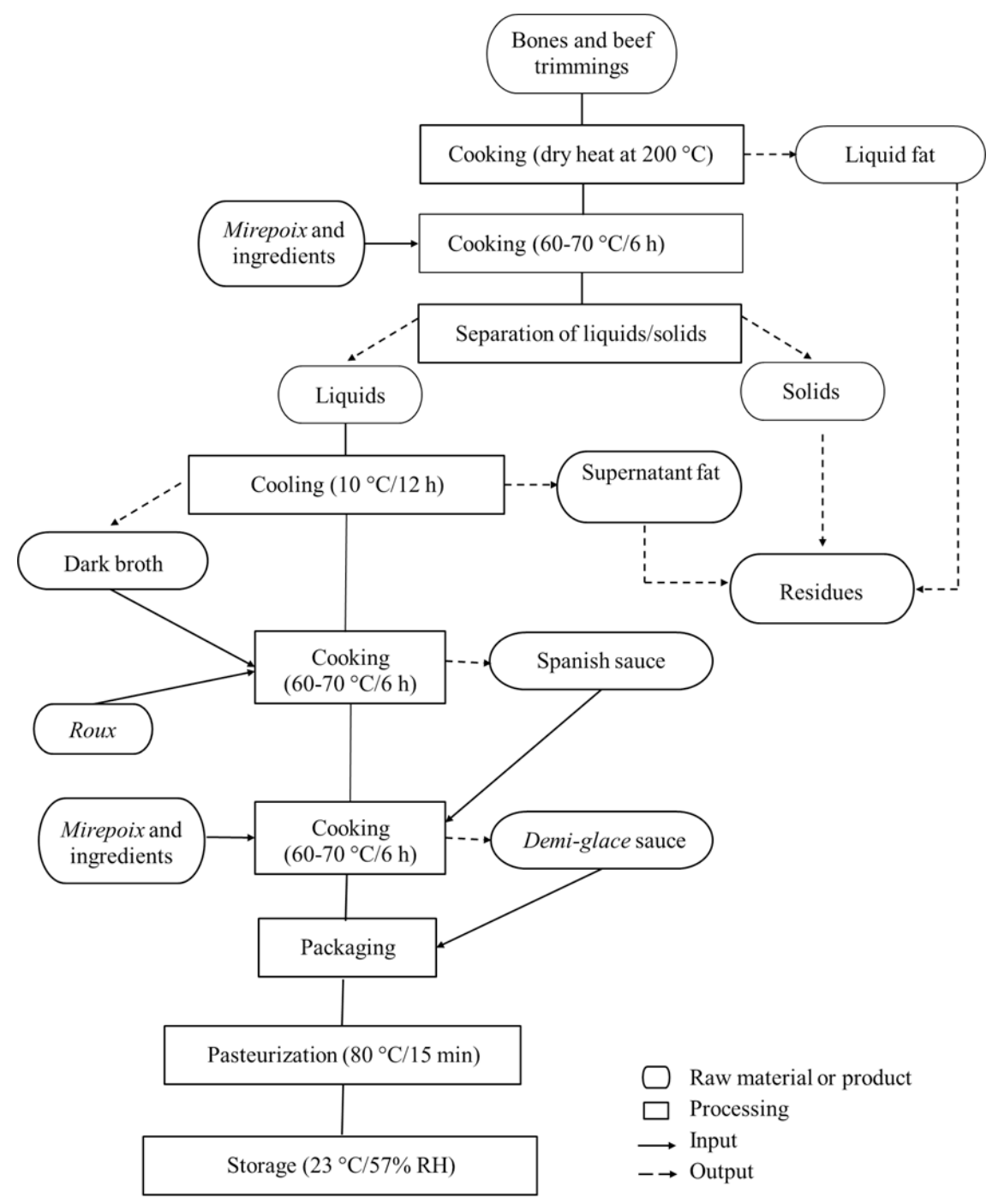

Figure 1. Flowchart of artisanal demi-glace sauce processing.

the supernatant fat (discarded along with the solid phase) giving the dark broth.

During the second stage, i.e., preparation of the Spanish sauce, melted margarine was homogenized with wheat flour until forming a uniform and smooth paste (roux). Then, the dark broth was gradually added, stirring continuously, until forming a sweet and fortified sauce (Spanish sauce).

During the third stage, and for the preparation of the demi-glace sauce, a portion of the mirepoix (carrot, onion and celery) was braised with garlic, olive oil and red wine to form a vegetable broth. Tomato sauce and dry red wine were then added to the Spanish sauce. The mixture was kept warm $\left(60-70{ }^{\circ} \mathrm{C}\right)$ to reduce the volume. The fat layer was removed whenever it appeared on the surface of the sauce. When ready, the sauce was pasteurized in sterile glass containers.

\section{Commercial demi-glace sauce}

According to the manufacturer, commercial powdered demiglace sauce contains starch, wheat flour enriched with iron and folic acid, bovine fat, yeast extract, salt, tomato, chicory, onion, sugar, flavoring, anti-fouling silicon dioxide, caramel and natural urucum dyes, disodium inosinate flavor enhancer and citric acid acidulant. For this study, the commercial demi-glace sauce was hydrated by diluting $100 \mathrm{~g}$ of the powder (commercially available form) in 1 liter of heated water $\left(45 \pm 5^{\circ} \mathrm{C}\right)$. Thereafter, this solution was heated to $100^{\circ} \mathrm{C}$ and kept at $65 \pm 5^{\circ} \mathrm{C}$ for 3 minutes. After this process, the hydrated sauce was packaged in sterile glass containers, pasteurized $\left(80^{\circ} \mathrm{C} / 15\right.$ minutes $)$ and cooled.

The end of the processes, the artisanal and the hydrated commercial demi-glace sauces were stored at room temperature $\left(23^{\circ} \mathrm{C}\right)$ and average relative humidity of $57 \%$.

\subsection{Sensory aspects}

The demi-glace sauce samples were submitted to sensory evaluations. The research project was submitted to analysis by the Committee of Ethics in Researches in Humans - CEP, IFCE, under decree 1.628.204, aiming at complying with the items in Resolution No. 466, 12/12/2012 of the National Health Council (CNS), which provides on ethics in researches involving human beings (Brasil, 2013). 
The sensory aspects were evaluated considering visual (color and stability) and olfactory (smell) parameters every 15 days during 75 days of storage ( $\mathrm{t} 1$ to t6). The Quality Index Method (QIM) adapted from Freitas \& Amaral (2011) was used. This method was developed to evaluate the freshness of fish through a system of demerit points. It is based on an objective, reliable and standardized assessment of the main sensory attributes taking into account distinctive characteristics of appearance, odor and texture that change during the time of storage.

To evaluate quality, a trained team of judges scored the food following a maximum 0-2 scale for each of the defined descriptors. All attributes were evaluated in the same order, and the scores are generated independently, resulting in a final overall score called Quality Index.

The criteria and the specific sensory descriptors of the demi-glace sauce using QIM were defined by a team of five people and are part of the Product Quality Index protocol, which has with three attributes with three descriptors each (Table 1).

The descriptors used to identify the changes are unambiguous, clear and brief, usually involving only one or two words to minimize any confusion on the part of the evaluators. The QIM presents advantages over other descriptive methods, mainly due to the rapidity and short training period of the evaluation team.

The descriptors corresponding to the state of highest quality are scored with 0 , whereas those referring to the more advanced degradation states are quoted with 2 . Therefore, the quality index (result of the sum of the dementia points) of the fresh demi-glace (0) and increases as the deterioration proceeds to a total of six (6).

\subsection{Microbiological analyses}

Microbiological analyses of the artisanal and commercial demi-glace sauces were conducted according to the parameters established by the current legislation (Brasil, 2001). Fecal coliform counts searching for Salmonella sp. and counts of Staphylococcus aureus were performed.

\section{Thermotolerant coliforms}

Aliquots $10 \mathrm{~g}$ from each demi-glace sauce sample were weighed aseptically and homogenized with $90 \mathrm{~mL}$ of previously sterilized $0.85 \%$ saline solution. The multiple tubes technique was used, with three sets of three tubes for each dilution $\left(10^{-1}, 10^{-2}\right.$ and $\left.10^{-3}\right)$. A lactose broth with incubation at $35^{\circ} \mathrm{C}$ for 48 hours was used as a presumptive medium. Then, total coliforms were counted from positive-reading tubes (turbidity and gas formation) using the brilliant green bile broth (BVB) with incubation at $35^{\circ} \mathrm{C}$ for 48 hours. For the count of thermotolerant coliforms, the tubes with production of gas were used for BVB and one portion of each tube was transferred into to tubes with E. coli (EC) broth. Then, the tubes were incubated at $45^{\circ} \mathrm{C}$ in water bath for 24 hours. The count in MPN (Most Probable Number) of total and fecal coliforms was determined by the Hoskins table from the number of positive tubes in the different dilutions used. To confirm the presence of $E$. coli, the positive tubes with EC broth were transferred into Petri dishes containing agar methylene blue eosin incubated at $35^{\circ} \mathrm{C}$ for 24 hours for a later observation of the presence of suspect colonies (Silva et al., 2001).

\section{Salmonella sp.}

To search for Salmonella sp., $25 \mathrm{~g}$ of the sample were homogenized in $225 \mathrm{~mL}$ of BPW and incubated in an oven at $35^{\circ} \mathrm{C}$ for 24 hours (pre-enrichment). After this time, $1 \mathrm{~mL}$ aliquots were transferred to tubes containing selenite cystine broth (CB) and tetrathionate broth (TT) for further incubation $\left(35^{\circ} \mathrm{C}\right)$ in water bath (selective enrichment). Then, peals were performed on Salmonella Shigella (SS), brilliant green agar (VB) and xylose lysine desoxilate agar (XLD) agar plates incubated at $35^{\circ} \mathrm{C}$ for $24 \mathrm{~h}$. Typical colonies were transplanted into slant tubes with lysine iron agar (LIA) and triple sugar iron agar (TSI), and incubated for $24 \mathrm{~h}$ at $35^{\circ} \mathrm{C}$ (Silva et al., 2001).

\section{Staphylococcus aureus}

The count of Staphylococcus aureus was performed using a $3 \mathrm{M}$ Petrifilm ${ }^{\mathrm{TM}}$ plate according to the AOAC 991.14. The plate consists of a medium with modified Baird Parker nutrients. It is selective and differential for this microorganism. The plates were incubated at $35^{\circ} \mathrm{C}$ for 24 hours. Then, the reading of the plates with enumeration of red-violet typical colonies surrounded by a pinkish area identified as $S$. aureus was performed. The confirmation was made by a thermostable thermonuclease reaction using a reactive disk inserted into the plate, producing a sharp pink color around the colonies (3M do Brasil Ltda., 2016).

\subsection{Lipid oxidation}

The lipid oxidation was evaluated from substances reactive to thiobarbituric acid (TBA) which quantifies malonaldehyde, one of the main decomposition products of hydroperoxides from polyunsaturated fatty acids formed during the oxidation

Table 1. QIM for the evaluation demi-glace sauce stored for 75 days at room temperature $\left(23^{\circ} \mathrm{C}\right)$ and at a relative humidity of $57 \%$.

\begin{tabular}{|c|c|c|c|}
\hline \multicolumn{2}{|c|}{ Quality attributes } & Descriptors & Demerit points \\
\hline \multirow{6}{*}{ Visual } & \multirow{3}{*}{ Color } & Conservation of original color & 0 \\
\hline & & Slight change in color & 1 \\
\hline & & Evident change in color & 2 \\
\hline & \multirow{3}{*}{ Stability } & Homogeneous liquid & 0 \\
\hline & & Turbid liquid & 1 \\
\hline & & Liquid with phase separation & 2 \\
\hline \multirow{3}{*}{ Olfactory } & \multirow{3}{*}{ Odor } & Pleasant and characteristic of the original product & 0 \\
\hline & & Different from the characteristic of the original product & 1 \\
\hline & & Unpleasant & 2 \\
\hline
\end{tabular}


process (Osawa et al., 2005). This method is based on the quantification of pigments measured in a spectrophotometer at $532 \mathrm{~nm}$ (Vyncke, 1970).

\subsection{Statistical analysis}

The experimental design was completely randomized, with three replications in a $2 \times 6$ factorial scheme, two treatments (artisanal demi-glace sauce and commercial demi-glace sauce hydrated) and six evaluation times ( $0,15,30,45,60$ and 75 days).

The results of the lipid oxidation analysis were presented as means \pm SD. Analysis of Variance (ANOVA) was used to assess this results and Student's t-test to compare the averages $(\mathrm{p}<0.05)$ using the Statistica 7.0 software (Statsoft, 2007).

\section{Results and discussion}

\subsection{Sensory aspects}

Upon evaluating the sensory quality of the demi-glace sauces using QIM, it was observed that the changes in sensory aspects occurred gradually over the 75 days of storage.

In the times from $\mathrm{t} 1$ ( 0 days) to $\mathrm{t} 3$ (30 days), artisanal and commercial demi-glace sauces showed no sensory change, either visual or olfactory, classifying them as excellent, totaling 0 demerit points (Figure 2).

From 44 (45 days), it was found that the commercial sauce had a turbid appearance, followed by separation of phases. The upper part (oil) was more liquid and the lower part was more consistent at t5 (60 days). The artisanal demi-glace sauce was homogeneous throughout the storage period, remaining 0 points up to 5 (60 days) and 1 demerit point t6 (75 days) corresponding to the change in odor characteristic of the original product. Pires (2008) reports that a major challenge in the production of industrial-scale sauces is to maintain the stability of emulsions and its quality attributes for as long as possible.

Regarding color, the commercial demi-glace sauce showed a slight change at $\mathrm{t} 6$ (75 days), while the artisanal demi-glace sauce kept the original color until the end of the study.

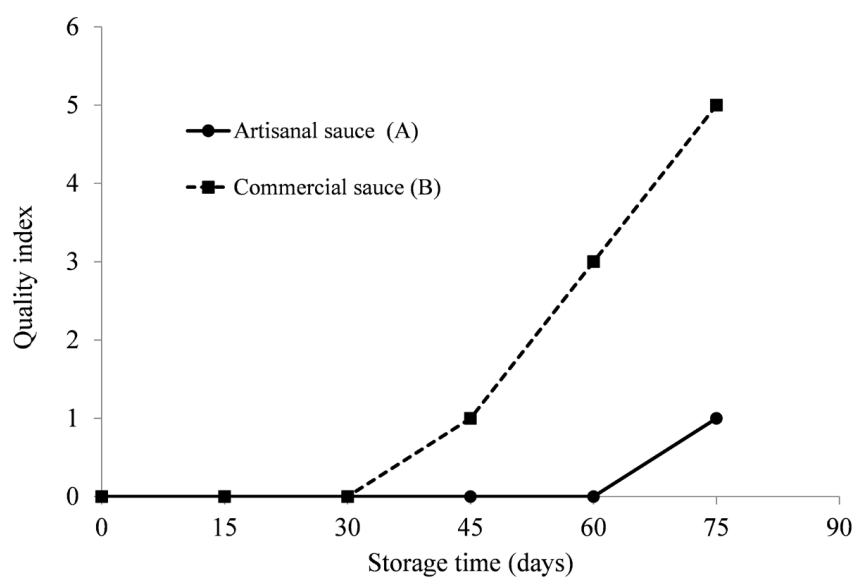

Figure 2. Quality Index of artisanal (A) and commercial (B) demi-glace sauces stored for 75 days at room temperature $\left(23^{\circ} \mathrm{C}\right)$ and at a relative humidity of $57 \%$.
Regarding the olfactory parameter, it was observed that, from $\mathrm{t} 5$ (60 days), the commercial demi-glace sauce changed the characteristic odor of the original product, evolving to an unpleasant odor at t6 (75 days). On the other hand, the artisanal demi-glace sauce was described with an odor different from the characteristic odor of the original product only at t6 (75 days).

The final scores obtained with the application of QIM for the storage of artisanal and commercial demi-glace sauces amounted to a total of 1 and 9 points at $t 6$, respectively, corresponding to approximately 3 and $25 \%$ of the maximum score (36 points). The greater the change, the higher the QIM product score. This allows stating that the sauces had excellent sensory results, especially the artisanal sauce (A), which showed only changes regarding odor, with one demerit point during the 75 days of storage.

\subsection{Microbiological analysis}

According to the results (Table 2), both the artisanal and the commercial demi-glace sauce showed a thermotolerant coliform count less than $3 \mathrm{MPN} / \mathrm{g}$, and absence of typical colonies of Staphylococcus aureus and Salmonella sp. in 25 g samples over the 75 days of storage. It thus meets the current law, which specifies limits of $5 \times 10 \mathrm{CFU} / \mathrm{g}, 5 \times 10^{2} \mathrm{CFU} / \mathrm{g}$ and absence in $25 \mathrm{~g}$ of sample, respectively (Brasil, 2001).

Since microorganisms are indicators of contamination and food deterioration, and the sauces have protein, lipid and carbohydrate levels sufficient for their development, it became clear that the raw materials had quality and a good origin. The handling at the processing of demi-glace sauce followed the requirements established by the Good Manufacturing Practices, and the storage of the products was adequate.

\subsection{Lipid oxidation}

The test quantified malonaldehyde, one of the main products of the decomposition of hydroperoxides from polyunsaturated fatty acids, formed during the oxidative process. The artisanal

Table 2. Microbiological composition of artisanal (A) and the commercial (B) demi-glace sauce.

\begin{tabular}{ccccc}
\hline $\begin{array}{c}\text { Storage times } \\
\text { (days) }\end{array}$ & Samples & $\begin{array}{c}\text { Coliform } 45^{\circ} \mathrm{C} \\
(\mathrm{MPN} / \mathrm{g})^{* *}\end{array}$ & $\begin{array}{c}\text { S. aureus } \\
(\mathrm{CFU} / \mathrm{g})^{* * *}\end{array}$ & $\begin{array}{c}\text { Salmonella sp. } \\
\text { (in 25 g) }\end{array}$ \\
\hline 0 & $\mathrm{~A}$ & $<3$ & 0 & Absence \\
& $\mathrm{B}$ & $<3$ & 0 & Absence \\
15 & $\mathrm{~A}$ & $<3$ & 0 & Absence \\
& $\mathrm{B}$ & $<3$ & 0 & Absence \\
30 & $\mathrm{~A}$ & $<3$ & 0 & Absence \\
& $\mathrm{B}$ & $<3$ & 0 & Absence \\
45 & $\mathrm{~A}$ & $<3$ & 0 & Absence \\
& $\mathrm{B}$ & $<3$ & 0 & Absence \\
60 & $\mathrm{~A}$ & $<3$ & 0 & Absence \\
& $\mathrm{B}$ & $<3$ & 0 & Absence \\
75 & $\mathrm{~A}$ & $<3$ & 0 & Absence \\
& $\mathrm{B}$ & $<3$ & 0 & Absence \\
Legislation & & $5 \times 10$ & $5 \times 10^{2}$ & Absence \\
\hline
\end{tabular}

${ }^{*}$ Limit results according to Brasil (2001); ${ }^{* *}$ most probable number; ${ }^{* * *}$ colony-forming units. 
Table 3. Lipid oxidation index of artisanal (A) and commercial (B) demi-glace sauces stored for 75 days at room temperature $\left(23^{\circ} \mathrm{C}\right)$ and at a relative humidity of $57 \%$.

\begin{tabular}{cccc}
\hline \multirow{2}{*}{ Storage times (days) } & \multicolumn{2}{c}{ Contents of malonaldehyde $(\mu \mathrm{g} / \mathrm{g})$} \\
\cline { 2 - 4 } & & $\mathrm{A}$ & $\mathrm{B}$ \\
\hline $\mathrm{t} 1$ & 0 & $0.11 \mathrm{a} \pm 0.00$ & $0.09 \mathrm{~b} \pm 0.00$ \\
$\mathrm{t} 2$ & 15 & $0.13 \mathrm{a} \pm 0.01$ & $0.10 \mathrm{~b} \pm 0.01$ \\
$\mathrm{t} 3$ & 30 & $0.18 \mathrm{a} \pm 0.01$ & $0.20 \mathrm{a} \pm 0.02$ \\
$\mathrm{t} 4$ & 45 & $0.33 \mathrm{a} \pm 0.01$ & $0.21 \mathrm{~b} \pm 0.02$ \\
$\mathrm{t} 5$ & 60 & $0.36 \mathrm{a} \pm 0.01$ & $0.32 \mathrm{~b} \pm 0.01$ \\
$\mathrm{t} 6$ & 75 & $0.58 \mathrm{a} \pm 0.02$ & $0.62 \mathrm{a} \pm 0.02$ \\
\hline
\end{tabular}

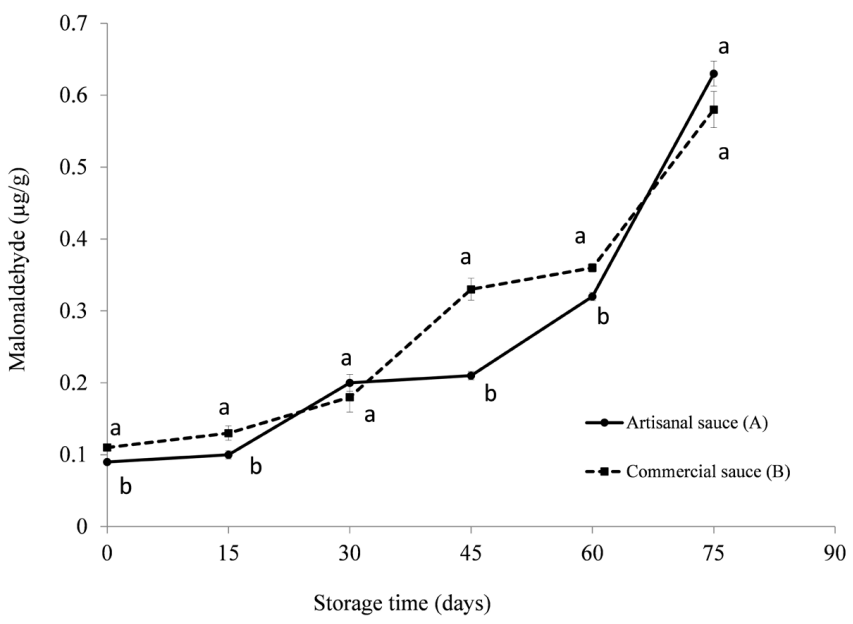

Figure 3. Lipid oxidation index of artisanal (A) and commercial (B) demi-glace sauces stored for 75 days at room temperature $\left(23^{\circ} \mathrm{C}\right)$ and at a relative humidity of $57 \%$.

(A) and commercial (B) demi-glace sauces showed a significant difference $(\mathrm{p}<0.05)$ at $\mathrm{t} 1, \mathrm{t} 2, \mathrm{t} 4$ and $\mathrm{t} 5$, when the artisanal sauce had lower contents of malonaldehyde $(18,23,36$ and $11 \%$, respectively), compared to the commercial sauce. Only at the $30^{\text {th }}$ and $75^{\text {th }}$ day of storage there was a significant similarity, with an average value of 0.19 and $0.61 \mu \mathrm{g} / \mathrm{g}$ of malonaldehyde in the sauces, respectively (Table 3 and Figure 3 ).

The condiments used mainly to make the food more enjoyable have a conservative action, inhibiting or delaying the microbial activity, and also retarding the oxidation of lipids (Kufner, 2010). Spices such as black pepper, rosemary, bay leaf and celery were used in the processing of the artisanal demi-glace sauce (A), different from the commercial demi-glace (B) sauce, which, in addition to spices, presented, according to the label, citric acid in its composition, a synthetic $\mathrm{pH}$ regulator and antioxidant conservative, which may prolong the life of the product. Although the artisanal demi-glace sauce does not contain conservatives, its shelf life was similar to the commercial product.

\section{Conclusion}

The artisanal demi-glace sauce showed little visual sensory and olfactory changes over the 75 days of storage at room temperature $\left(23{ }^{\circ} \mathrm{C}\right)$ and at a relative humidity of $57 \%$. The commercial demi-glace sauce presented changes from the $30^{\text {th }}$ day of storage, particularly with regard to phase separation even if it contained conservatives such as citric acid in its composition.

The artisanal and commercial demi-glace sauces complied with the microbiological standards set by the Brazilian legislation, demonstrating the adequacy to the Good Manufacturing Practices during its production. Besides, it also showed a similar oxidative stability only at the $30^{\text {th }}$ and $75^{\text {th }}$ day of storage, when malonaldehyde values $(\mathrm{mg} / \mathrm{g})$ of the artisanal sauce were significantly equal in relation to the commercial sauce.

Although the artisanal demi-glace sauce does not contain conservatives, its shelf life was similar to the hydrated commercial product.

\section{References}

3M do Brasil Ltda. (2016). Microbiologia Petrifilm ${ }^{\mathrm{Ts}}$ - Placas para contagem de Staphylococcus aureus: instruções de uso. Retrieved from www.3M.com.br

Almeida, J. F., Reis, A. S., Heldt, L. F. S., Pereira, D., Bianchin, M., Moura, C., Plata-Oviedo, M. V., Haminiuk, C. W. I., Ribeiro, I. S., Luz, C. F. P., \& Carpes, S. T. (2017). Lyophilized bee pollen extract: a natural antioxidant source to prevent lipid oxidation in refrigerated sausages. Lebensmittel-Wissenschaft + Technologie, 76, 299-305. http://dx.doi.org/10.1016/j.lwt.2016.06.017.

Barreto, R. L. P. (2010). Passaporte para o sabor: tecnologias para a elaboração de cardápios (8. ed.). São Paulo: SENAC.

Brasil. Ministério da Saúde. (2001). Secretaria de Vigilância Sanitária. Regulamento técnico sobre padrões microbiológicos para alimentos (Resolução RDC n ${ }^{\circ}$ 2, de 2 de janeiro de 2001). Diário Oficial [da] República Federativa do Brasil.

Brasil. Ministério da Saúde. (2013, Junho 13). Aprova as diretrizes e normas regulamentadoras de pesquisas envolvendo seres humanos (Resolução n ${ }^{\circ} 466$ do Conselho Nacional de Saúde, de 12 de dezembro de 2012). Diário Oficial [da] República Federativa do Brasil, nº 12, seção 1, p. 59.

Forsythe, S. J. (2013). Microbiologia da segurança dos alimentos (2. ed.). Porto Alegre: Artmed.

Freitas, D. G. C., \& Amaral, G. V. (2011). Método do índice de qualidade (MIQ) para a avaliação sensorial da qualidade de pescado (Embrapa Agroindústria de Alimentos. Documentos, Vol. 112). Rio de Janeiro: Embrapa Agroindústria de Alimentos.

Kufner, D. E. (2010). Atividade antioxidante do extrato aquoso de manjerona (Origanum manjerona L.), em linguiça frescal de frango (Dissertação de mestrado). Universidade Regional Integrada do Alto Uruguai e das Missões, Erechim.

Moura, S. C. S. R., Berbari, S. A., Germer, S. P. M., Almeida, M. E. M., \& Fefim, D. A. (2007). Determinação da vida-de-prateleira de maçãpassa por testes acelerados. Ciência e Tecnologia de Alimentos, 27(1), 141-148. http://dx.doi.org/10.1590/S0101-20612007000100025.

Osawa, C. C., Felício, P. E., \& Gonçalves, L. A. G. (2005). Teste de TBA aplicado a carnes e derivados: métodos tradicionais, modificados e alternativos. Quimica Nova, 28(4), 655-663.

Pires, M. H. (2008). Molho e a valorização do prato. Revista Nacional da Carne: Bovinos, Aves e Suínos, 32(374), 92-98.

Silva, N., Junqueira, V. C. A., \& Silveira, N. F. A. (2001). Manual de métodos de análise microbiológica de alimentos. São Paulo: Livraria Varela.

Statsoft. (2007). Statistica for Window - Computer programa manual, Versão 7.0. Tulsa: Statsoft Inc.

Vyncke, W. (1970). Direct determination of the TBA value in trichloroacetic acid extract of fish as a measure of oxidative rancidity. Fette Seifen Anstrichmittel, 72(12), 1084-1087. 